American Journal of Applied Sciences 8 (2): 172-176, 2011

ISSN 1546-9239

(C) 2010 Science Publications

\title{
A Study of Elementary School Students' Viewpoints on Interactive Whiteboard
}

\author{
${ }^{1}$ Tian-Syung Lan and ${ }^{1,2}$ Tsung-Yen Hsiao \\ ${ }^{1}$ Department of Information Management, Yu Da University, \\ Miaoli County, Taiwan 361, ROC \\ ${ }^{2}$ Jhushing Elementary School, Jhunan Township, \\ Miaoli County, Taiwan 35045, ROC
}

\begin{abstract}
Problem statement: Introducing the Interactive Whiteboard (IWB) into teaching is not only a current trend but also a major policy of education. Many studies indicated that IWB can increase the interaction between teachers and students as well as students' motivation and enjoyment from teachers' viewpoints. However, a study to understand and describe the opinion from children's view is hardly found. Approach: This study combined methods of Beeland, Hall and Higgins. The questionnaire and group interview were utilized to conclude the children's viewpoints of IWB. The questionnaire recreated by Beeland for enjoyment, anxiety, importance, skill and effect was employed to measure the extent what children's opinion from 50 middle and 46 high grade students. The scores of middle and high grade students were additionally compared to analyze the differences between two groups. In order to understand students' viewpoints on IWB, the discourse context after interview with students were moreover conducted. These discourse contexts were thus classified based on four main questions. Results: The results of this study indicated that there were significant differences of viewpoints on IWB between middle and high grade students. Conclusion: The teachers need to be aware of the potential questions that were revealed to teaching with IWB. Besides, the teachers should keep the feedback of students at group interview in mind and use this information effectively. The study can surely assist teachers to improve teaching with IWB and maintain student enjoyment on IWB.
\end{abstract}

Key words: Interactive whiteboard, enjoyment subscale, anxiety subscale, importance subscale, skill effect, Information and Communications Technology (ICT), Interactive Whiteboard (IWB), elementary education, discourse contexts, students' viewpoints

\section{INTRODUCTION}

Interactive Whiteboard (IWB) technology was used for presentations in business. Because of the popularization of computer, IWB has been used in elementary education (Buntod et al., 2010). Since 1997, the government of United Kingdom has greatly invested in Information and Communications Technology (ICT) for education, including interactive whiteboard. The government believes that IWB will raise children's study efficiency. Australia and America have also introduced IWB into elementary education. Many existing studies showed that IWB can increase interaction between teachers and students as well as students motivation and enjoyment (Smith et al., 2006). However, it is hardly found studies on IWB from children's viewpoints (Glover and Miller, 2001; Beauchamp, 2004).
Elliott (2005) indicated that children are neither to be understood nor to describe their opinion because lots of studies neglect what children think. Kirby et al. (2003) showed the government inverted lots of money in education, but children have not had their response in education. Murphy and Beggs (2003) also pointed out that there were few studies to find out children how they feel and how they think about IWB. It is shown (DFES, 2003) that children's viewpoints can not only help teachers know how to enhance the students' understand in classroom by IWB, but also increase interaction during teaching. Caylak (2010) described that children have different points of view to teachers and those viewpoints need to be discussed. Based on the above, it is necessary to study children's aspects of IWB and Information Technology (IT) in teaching.

Background: There are more and more studies about Information Technology using in teaching. The

Corresponding Author: Tian-Syung Lan, Department of Information Management, Yu Da University Miaoli County, Taiwan 361, R.O.C 
resources indicated that IWB raises not only children's study motivation but also teacher's teaching efficiency (Smith, 2009; Glover and Miller, 2001; Levy, 2002). IWB can be a tool for teaching and a tool for learning (Thomas, 2002; Boyle, 2002). It is illustrated that IWB is the flexible and versatile teaching tool. It can be used from nursery to higher education as well as distant education. Smith (2009) indicated when children writing on IWB, children's writing skill can thus be improved. Goodison (2002) reported that compare to mouse and keyboard IWB is easier to use. Glover and Miller (2001) found that nurseries are more interesting in IWB when introduced it to 29 nurseries. Additionally, they can do the activities on IWB without well skills. Levy's interviewed with secondary school teachers and found that there were many resources can be used on IWB. The variety of IWB is also demonstrated (Levy, 2002). There are many researches showed that IWB can raise teaching efficient. However, those researches do not mention the difference between using computer and IWB in instruction. Thomas (2002) and Boyle (2002) said IWB is a more efficient presentation and more professional delivery of multimedia resources. It is also denoted (Virtual Learning, 2003) that IWB enables a smooth transition between activities in lesson. Children are motivated in lessons with IWB (Smith et al., 2006) and the motivation can raise the interest for children's study (Blane, 2003; Wiggins and Ruthmann, 2002).

Although IWB provides interaction between teachers and children, IWB does not have interaction function which is provided by software. Bell (2001) and levy (2002) provided that not all teachers agreed that IWB can increase interaction in lesson. Nevertheless, in Goodison's report, IWB in science course has more positive feedback than using in social science (Goodison, 2003). Even IWB is only a facility in classroom; İbrahim and Kazu (2009) indicated that applying IWB into teaching is the most important thing. Gatlin (2004) said that teachers could get feedback from children directly during teaching and focus on subjects that children do not know. Gage (2002) noted that teachers can have some interaction activities on IWB to make children familiar with using IWB. Based on the experiences provided by teachers who use IWB in classes, IWB indeed provides children motivation to join the classes. It can also raise children's attainment and concentration in the class. Because of the increasing usage of IWB, it is necessary to study children's viewpoints on the IWB.

Beeland (2002) researched and reorganized the Computer Attitude Questionnaire created by Christensen and Knezek for enjoyment, anxiety, importance, skill and effect to measure the extent of children's opinion. The results indicated that children have high interest and concentration in IWB. Hall and Higgins (2005) interviewed 72 children (10 year-old) about their opinion on IWB and showed IWB brings enjoyment into class. However, children also showed technical problems and lack of skill in using IWB.

The studies of Beeland (2002), Hall and Higgins (2005) provided many viewpoints from children, but the results of these studies do not have enough data to evaluate the viewpoints of children. Therefore, this study will combine the methods of Beeland and Hall and Higgins, to analyze children's viewpoints of IWB using questionnaire and group interview.

The purpose of this study is to determine the difference of the viewpoints about IWB from elementary students. This study aims to answer the following question:

- Do the viewpoints about IWB show differences between middle and high grade students?

- What do students describe the experiences about IWB in interview?

\section{MATERIALS AND METHODS}

Participants: Participants are divided into middle grade group from Grade 3 and Grade 4 and high grade group from Grade 5 and Group 6 students in four classes. All participants will fill out the questionnaire about Interactive Whiteboard and receive group interview. The total number of students who completed the questionnaire was 96 .

Measures: Two surveys were administered for identifying the two groups.

Viewpoints about interactive whiteboard scale: The scale based on a modified version of the student engagement in an interactive whiteboard is originally created by Beeland (2002). The scale has five subscales including enjoyment ( 8 items), anxiety ( 8 items), importance ( 8 items), skill ( 8 items) and effect ( 8 items). The reported internal consistencies for five subscales were assessed by computing Cronbach's $\alpha$ between 0.698 and 0.839 (Table 1). All subscales had significant correlations between 0.424-0.697 (Table 2).

It measured as students responded to each forty questions on a 1-4 scale. A response of 1 indicated that the student strongly disagreed with the statement, 2 signified disagreed, 3 agreed and 4 strong agreed. 
Am. J. Applied Sci., 8 (2): 172-176, 2011

Table 1: Cronbach's $\alpha$ of Viewpoints about interactive whiteboard scale's subscales

\begin{tabular}{|c|c|c|c|c|c|}
\hline & Enjoyment & At Anxiety & Importance & Skill & Effect \\
\hline Cronbach's o & $\begin{array}{ll}x & 0.819\end{array}$ & 0.813 & 0.721 & 0.697 & 0.839 \\
\hline \multicolumn{6}{|c|}{$\begin{array}{l}\text { Table 2: Correlations of Viewpoints about interactive whiteboard } \\
\text { scale's subscales }\end{array}$} \\
\hline & Enjoyment & Anxiety & Importance & Skill & Effect \\
\hline Enjoyment & 1.000 & & & & \\
\hline Anxic & $0.697 * *$ & 1.000 & & & \\
\hline Importance & 0.734 & $0.596^{* *}$ & 1.000 & & \\
\hline Skill & $0.424 * *$ & $0.543 * *$ & $0.560^{* *}$ & 1.000 & \\
\hline Effect & $0.627^{* *}$ & $0.532 * *$ & $0.691 * *$ & $0.475^{* *}$ & 1 \\
\hline
\end{tabular}

The scoring scale for questions $5,7,11,13,14,15,20$, $25,27,29,35$ and 39 was reversed.

Group interview: The main questions referred to Hall and Higgins (2005) were:

- What advantages does IWB have over a traditional whiteboard or blackboard?

- Do you believe you are able to learn better when IWB is used in the classroom? If so, in what ways are you able to learn better?

- Have you noticed any problems with IWB?

- What could your teacher do with the IWB to make your lessons more interesting?

Procedures: In order to understand a viewpoint about IWB, all participants will fill out Viewpoints about interactive whiteboard scale before group interview. Groups were composed of 15 students and seven group interviews were conducted. Participants in the interview extracts are identified using the following notation: S196 (Student 1-96).

Data analysis: To compare the middle and high grade groups on the viewpoints about interactive whiteboard scale, the quantitative analysis of the collected data was conducted through one-way ANOVA. In addition to understand viewpoints about IWB, the discourse contexts of group interview were qualitatively analyzed.

\section{RESULTS}

Table 3 shows the Mean (M), Standard Deviation (SD) and significant difference on item of subscale for one-way ANOVA by grade.

Enjoyment subscale: In enjoyment subscale, there was significant difference between middle and high grade students on item 2-- I enjoy lessons on the interactive whiteboard.

Anxiety subscale: In anxiety subscale, there was significant difference between middle and high grade students on item 10-- Using a white board doesn't make me nervous.
Table 3: Mean, standard deviation, one-way ANOVA on scores of the subscales by grade

\begin{tabular}{|c|c|c|c|c|c|c|}
\hline Subscale & Item & Grade & M & SD & $\mathrm{F}$ & Sig. \\
\hline \multirow[t]{2}{*}{ Enjoyment } & \multirow[t]{2}{*}{2} & Middle & 3.28 & 0.114 & \multirow[t]{2}{*}{$1.71 *$} & \multirow[t]{2}{*}{0.039} \\
\hline & & High & 3.59 & 0.091 & & \\
\hline \multirow[t]{2}{*}{ Anxiety } & \multirow[t]{2}{*}{10} & Middle & 3.26 & 0.114 & \multirow[t]{2}{*}{$5.55^{*}$} & \multirow[t]{2}{*}{0.020} \\
\hline & & High & 2.80 & 0.154 & & \\
\hline \multirow[t]{8}{*}{ Importance } & \multirow[t]{2}{*}{19} & Middle & 1.98 & 0.144 & \multirow[t]{2}{*}{$0.852 * *$} & \multirow[t]{2}{*}{0.002} \\
\hline & & High & 2.63 & 0.150 & & \\
\hline & \multirow[t]{2}{*}{21} & Middle & 3.42 & 0.122 & \multirow[t]{2}{*}{$6.17 * *$} & \multirow[t]{2}{*}{0.000} \\
\hline & & High & 2.43 & 0.160 & & \\
\hline & \multirow[t]{2}{*}{23} & Middle & 2.48 & 0.125 & \multirow[t]{2}{*}{$0.671 * *$} & \multirow[t]{2}{*}{0.001} \\
\hline & & High & 3.09 & 0.128 & & \\
\hline & \multirow[t]{2}{*}{24} & Middle & 1.82 & 0.127 & \multirow[t]{2}{*}{$4.21 * *$} & \multirow[t]{2}{*}{0.000} \\
\hline & & High & 2.57 & 0.151 & & \\
\hline \multirow[t]{4}{*}{ Skill } & \multirow[t]{2}{*}{26} & Middle & 3.32 & 0.112 & \multirow[t]{2}{*}{$13.23 *$} & \multirow[t]{2}{*}{0.022} \\
\hline & & High & 2.85 & 0.167 & & \\
\hline & \multirow[t]{2}{*}{32} & Middle & 2.18 & 0.168 & \multirow[t]{2}{*}{$19.14^{* *}$} & \multirow[t]{2}{*}{0.000} \\
\hline & & High & 3.26 & 0.114 & & \\
\hline
\end{tabular}

$*: \mathrm{p}<0.05 ; * *: \mathrm{p}<0.01$

Importance subscale: In importance subscale, there was significant difference between middle and high grade students on item 19-- I think that every lesson should be taken by a interactive whiteboard, item 21-- I would take more time to learn when teacher uses a white board, item 23-- I think it is important for teacher to use a interactive whiteboard on instruction and item 24-- I think interactive whiteboard will replace computer. It reported middle grade students $(\mathrm{M}=1.98, \mathrm{SD}=0.150)$ didn't think every lesson should be taken with interactive whiteboard than high grade students $(\mathrm{M}=2.63, \mathrm{SD}=$ $0.114)$; middle grade students $(\mathrm{M}=3.42, \mathrm{SD}=0.122)$ would take more time to learn when teacher uses a white board than high grade students $(\mathrm{M}=2.43, \mathrm{SD}=0.160)$.

Skill subscale: In skill subscale, there was significant difference between middle and high grade students on item 26-- I think it is very inconvenient to orientate an interactive whiteboard; item 32-- I think it should be quicker on touch control functions of interactive whiteboard.

Group interview: Q1. What advantages does an IWB have over a traditional whiteboard or blackboard?

When students were asked what advantages the IWB have, they expressed similar views as:

- S3: It is fun and you can control IWB by hands.

- S9: IWB is animated.

- S77: It can combine with other facilities.

- S43: It makes lesson like game.

- S37: I don't need to clean the blackboard.

Q2. Do you believe you are able to learn better when an IWB is used in the classroom? If so, in what ways are you able to learn better? 
Over $90 \%$ students have positive comment on this question. Only a few students have opposite opinion as bellow:

- S51: If we can pay attention in lesson, we will learn better no matter using IWB or not.

- S34: It wastes time in the class.

- S68: Teachers spent much time in operating IWB.

- Q3. Have you noticed any problems with IWB?

Hardware of IWB can still be improved. The students provide their opinions as:

- S8: IWB can only be used by one at a time.

- S22: I don't like IWB because I have to orientate it and sometimes orientating wastes a lot of time.

- S69: Sometimes we can't see words on IWB because the light from the window shines on it.

- S77: Sometimes the pen doesn't work on IWB and you have to orientate it again.

- S86: I like IWB because I pay attention in the lesson.

- S90: IWB makes Math fun and we play Math games.

- S91: When IWB crashes, you have to turn it off and back on to reload everything up.

Q4. What could your teacher do with the IWB to make your lessons more interesting?

Students expect that IWB can make lesson more interesting. They provide their suggestions as:

- S7: It would be better to use IWB in every subject.

- S93: I hope that I have more time using IWB.

- S25: If material can become animation, the lesson will be more interesting.

- S74: It will be much fun if more than one person can operate IWB at the same time.

\section{DISCUSSION}

Enjoyment subscale: According to mean in Table 3, it reflected that high grade $(\mathrm{M}=3.59, \mathrm{SD}=0.091)$ students were much more enjoyed in interactive whiteboard than middle grade students $(\mathrm{M}=3.28, \mathrm{SD}=0.114)$.

Anxiety subscale: According to mean in Table 3 , it reflected that high grade students $(\mathrm{M}=2.80, \mathrm{SD}=$

0.154 ) feel more nervous in using interactive

whiteboard than middle grade students $(\mathrm{M}=3.26, \mathrm{SD}=$ $0.114)$.

Importance subscale: According to mean in Table 3, it reflected that middle grade students think that every lesson should be taken by an interactive whiteboard and want to take more time to learn when teacher uses a interactive whiteboard. The high grade students think it is important for teacher to use a interactive whiteboard on instruction and interactive whiteboard will replace the computer.

Skill subscale: Because item 26 was reversed, according to mean in Table 3, it reflected that middle grade students $(\mathrm{M}=3.32, \mathrm{SD}=0.112)$ don't think it is very inconvenient to orientate an interactive whiteboard than high grade students $(\mathrm{M}=2.85, \mathrm{SD}=0.167)$. High grade students $(\mathrm{M}=3.26, \mathrm{SD}=0.114)$ think it should be quicker on touch control functions of interactive whiteboard than middle grade students $(\mathrm{M}=2.18, \mathrm{SD}=$ $0.168)$.

\section{CONCLUSION}

The purpose of the study is to explore the elementary school students' viewpoints on interactive whiteboard. The sample was taken from 96 students from the 3rd to the 6th grade students in a same school.

It is shown that there was significant difference between middle and high grade students on enjoyment, anxiety, importance and skill subscales. The findings in this study are concluded and listed as follows:

- There was significant difference between middle and high grade students on "I enjoy lessons on the interactive whiteboard" of enjoyment subscale

- There was significant difference between middle and high grade students on using an interactive white board doesn't make me nervous" of anxiety subscale

- There were significant differences between middle and high grade students on "I think that every lesson should be taken by an interactive whiteboard", "I would take more time to learn when teacher uses an interactive whiteboard", "I think it is important for teacher to use an interactive whiteboard on instruction" and "I think interactive whiteboard will replace computer" of importance subscale

- There were significant differences between middle and high grade students on "I think it is very inconvenient to orientate an interactive whiteboard" and "I think it should be quicker on touch control functions of interactive whiteboard" of skill subscale

- There was no significant difference between middle and high grade students on effect subscale

- In the group interview, students expressed a lot of viewpoints including technical problems, advantage of IWB and situations of teaching with IWB in class 


\section{REFERENCES}

Beauchamp, G., 2004. Teacher use of the interactive whiteboard in primary schools: Towards an effective transition framework. Technol. Pedagogy Educ., $\quad$ 13: $327-348 . \quad$ DOI: $10.1080 / 14759390400200186$

Beeland, W.D., 2002. Student engagement, visual learning and technology: Can interactive whiteboards help? http://vtext.valdosta.edu/xmlui/handle/10428/31

Bell, M.A., 2001. Update to survey of use of interactive electronic whiteboard in instruction. Sam Houston State

University. http://www.shsu.edu/ lis_mah/documents/updateb oardindex.htm

Blane, D., 2003. Access across the board. Times Educational Supplement. http://www.tes.co.uk/article.aspx?storycode $=376326$

Boyle, J., 2002. Virtual magic. Times Educational Supplement. http://www.tes.co.uk/article.aspx?storycode $=362633$

Caylak, D.E., 2010. The studies about phonological deficit theory in children with developmental dyslexia: review. Am. J. Neurosci., 1: 1-12. DOI: 10.3844/ajnsp.2010.1.12

DFES, 2003. Information and Communications Technology in Schools in England. Department for Education and Skills. London. http://www.education.gov.uk/rsgateway/DB/SFR/s 000480/index.shtml

Elliott, B.J., 2005. Using narrative in social research: qualitative and quantitative approaches. 1st Edn., SAGE, London, ISBN-10: 1412900417, pp: 220.

Gage, J., 2002. So what is an electronic whiteboard? Should you want one? Micro Math., 8: 5-7.

Gatlin, M., 2004. Interactive whiteboard system creates 'active classrooms' for rural Georgia school system. T. H. E. J., 31: 50-52.

Glover, D. and D. Miller, 2001. Running with technology: the pedagogic impact of the large-scale introduction of interactive whiteboards in one secondary school. J. Inform. Technol. Teacher Educ., $\quad 10$ : 257-278. $\quad$ DOI: $10.1080 / 14759390100200115$

Goodison, T., 2002. ICT and attainment at primary level. Brit. J. Educ. Technol., 33: 201-211. DOI: 10.1111/1467-8535.00253

Goodison, T., 2003. Integrating ICT in the classroom: a case study of two contrasting lessons. Brit. J. Educ. Technol., 34: 549-566. DOI: 10.1046/j.00071013.2003.00350.x
Hall, I. and S. Higgins, 2005. Primary school students' perceptions of interactive whiteboards. J. Comp. Assisted Learn., 21: 102-117. DOI: 10.1111/j.1365-2729.2005.00118.x

Kazu, I.Y., 2009. The effect of learning styles on education and the teaching process. J. Soc. Sci., 5: 85-94. DOI: 10.3844 /jssp.2009.85.94

Kirby, P., C. Lanyon, K. Cronin and R. Sinclair, 2003. Building a culture of participation involving children and young people in policy, service planning, delivery and evaluation. Department for Education and Skills, England. http://publications.education.gov.uk/eOrderingDow nload/DfES-0826-2003.pdf

Levy, P., 2002. Interactive Whiteboards in learning and teaching in two Sheffield schools: A developmental study. University of Sheffield, Sheffield, YS, England. http://dis.shef.ac.uk/eirg/projects/wboards.htm

Murphy, C. and J. Beggs, 2003. Primary pupils' and teachers' use of computers at home and school. Brit. J. Edu. Technol., 34: 79-83.

Buntod, P.C., P. Suksringam and A. Singseevo, 2010. Effects of learning environmental education on science process skills and critical thinking of mathayomsuksa 3 students with different learning achievements. J. Soc. Sci., 6: 60-63. DOI: $10.3844 /$ jssp. 2010.60 .63

Smith, A., 2009. Interactive whiteboard evaluation. Boston Spa Comprehensive School. Boston, MA. http://www.mirandanet.ac.uk/pubs/smartboard.htm

Smith, F., F. Hardman and S. Higgins, 2006. The impact of interactive whiteboards on teacher-pupil interaction in the national literacy and numeracy strategies. Brit. Edu. Res. J., 32: 443-457. DOI: 10.1080/01411920600635452

Thomas, A., 2002. The white stuff. Times Educational Supplement.

http://www.tes.co.uk/article.aspx?storycode=369864

Virtual Learning, 2003. Interactive whiteboards case studies: New tools, new pedagogies, new learning,"virtuallearning.org, http://www.virtuallearning.org.uk/?page_id=163

Wiggins, J. and A. Ruthmann, 2002. Music teachers' experiences: Learning through SMART board technology. Oakland University. Rochester, MI http://downloads01.smarttech.com/media/sitecore/e $\mathrm{n} / \mathrm{pdf} / \mathrm{research}$ library/music/music_teachers_expe rienceslearning_through_smart_board_technology.pdf 